\title{
The Simultaneity of Corporate Financial Decisions Under Different Levels of Managerial Ownership: A Case of Pakistani Listed Firms
}

\author{
Mohamad Helmi bin Hidthiir ${ }^{1}$, Muhammad Farhan Basheer $^{1} \&$ Saira Ghulam Hassan ${ }^{1}$ \\ ${ }^{1}$ School of Economics, Finance \& Banking (SEFB), College of Business (COB), University Utara Malaysia (UUM), \\ Malaysia \\ Correspondence: Dr. Mohamad Helmi bin Hidthiir, School of Economics, Finance \& Banking (SEFB), College of \\ Business (COB), University Utara Malaysia (UUM), Malaysia.
}

Received: May 1, 2019

doi:10.5430/rwe.v10n2p147
Accepted: June 1, 2019

Online Published: July 9, 2019

URL: https://doi.org/10.5430/rwe.v10n2p147

\begin{abstract}
Purpose- The prime objective of the current study is to investigate the interdepended of financial decision. In addition to that the impact of different level of managerial ownership on the interdepended of financial decisions is also examined agency theory, pecking order theory and the signaling theory are used as the theoretical lenses to draw the theocratical framework.

Design/methodology/approach- The balance panel of 161 nonfinancial firm over the period of five years from 2013 to 2017 is used to achieve the research objectives. Polled OLS, Fixed effect and Random effect estimates are employed to answer the reach questions

Findings- The managerial ownership with an average mean ownership of 39 is appeared at the top. Interestingly more than 75 percent firms are being controlled by mangers and in more than 60 percent firms of our sample the controlling managers hold more than 40 percent of shares. The Wu Hausman test is performed to determine the existence of the endogeneity problem. The results indicates that the financial decisions namely cash holding decisions, financing decisions and investment decisions has significant impact on each other. Where the managerial ownership is in nonlinear relationship with financial decisions. The results of the study are also providing support to agency theory, pecking order theory and the signaling theory
\end{abstract}

Research implications- The study will be helpful for policymakers, researchers, corporate personals and financial institutions in understanding the interrelationship between financing decisions and the role of managerial ownership in there interdepended.

Originality/value- The study is among the pioneering studies on the issue and will provide policy guideline on the said issues

Keywords: managerial ownership, investment, cash holdings, financing, listed, Pakistan

JEL Classification Code: G3

\section{Introduction}

The cash holdings are the percentage of cash and cash convertible to total asset (Basheer, 2014). The capital structure and cash holding decisions are among few very prominent determinants of agency conflicts. During last few decades their interface has gained an increasing amount of attention of both academician as well as practitioners. The squabble was started with the perfect market hypothesis proposed by Modigliani and Miller (MM) (1959). According to $\mathrm{MM}$, in a perfect market which is characterized as a market with no cost arising because of market imperfection such as opportunity cost, transaction cost, and agency cost, the managerial decsiuons such as financing, investment and cash holding decisions have no impact on firm value nor they have any interdependence between or among them. However, in real of imperfect market, where transacting parties are not equally rational, the imperfections prevail in the market. Therefore, soon many authors (Jensen, 1986; Basheer, 2014; Sheikh \&Wang, 2012; Sheikh \& Qureshi, 2017) have shown a disagreement with perfect hypothesis and provided evidences of market imperfections and their impact on firm decisions and ultimately on firm value. One of the theoretical justifications against the MM perfect market hypothesis was the agency theory, which argues that there exists a conflict of interest between mangers and owners, which ultimately leads firm with financial decision with negative net present value. 
Agency theory view of organziation considers orgaznaition as an living entity whoese value maximsation is a subject of conflict between the chief controlling authority (Chairman of Board) and chief decesional authority (Chief Exuctive officer). Agency theouy views the separation of risk baring function as main reaosn of agency conflict. The agency conflcit usually conceptulised as two distnict and linked conflicts known as principal agent and principal conflict.The tridtional conceptulization agency conflict which the principal agent conflict is the conflict between magers and owners. The ownership concentration and mangerial ownership is seen as a solution of this conflcit. However, the concentration of owenrship gives birth to another conflict between majority and maniority shareholders which is known as principal-priciapal (Sauerwald \&Peng, 2013; Chidoko and Mashavira, 2014; Salvioni and Gennari, 2014; Razek, 2014; Eshiet, 2017; Mejdoub and Arab, 2017; Oitsile., Galebotswe and Sekwati, 2018; Chang'ach, 2018; Chen, Musacchio \& Li, 2018). This conflicted relationship effect firm's decisions which in turn affect firm value. The corporate governance, capital structure, cash holding, and firm value decisions are central to this conflict.

According to pecking order theory, firms financing decesions are depdnent upon their level of retained earnings (Basheer, 2014; Ali, et. al. 2016; Omodero and Ogbonnaya, 2018). The cash holding are considered as most valueable and cheapest source of financing (Sheikh \& Wang, 2012; Romli and Ismail, 2014; Ekpung, 2014; Sarwar and Mubarik, 2014; Okon and Monday, 2017; Kimengsi and Gwan, 2017; Bollazzi and Risalvato, 2018). Agency theory argues that because of the information asymmetry between markets and frim management, the firm prefers internally generated finance than external financing. (Myers, 1984) This theory views that the tax and financial default are less important than tax shield. Therefore, the pecking order theory suggests that firms increasing cash level will be an indication that frim are reducing their relaying on risky debt financing or equity financing (Myers, 1989; Sheikh and Wang, 2012).

The managerial ownership (MO), which is the percentage of ownership by managers is seen as a solution of agency conflict. The managerial ownership helps the firm in aligning the interest of shareholders and managers. Many prior studies (Fama \& Jensen, 1983: Ozkan \&Ozkan, 2004; Basheer, 2014; Mishra et al., 2017; Sheikh \& Wang, 2012; Akhtar et al., 2018) have reported a significant relationship between managerial ownership and agency conflict. However, many of them (Basheer, 2014; Ozkan \& Ozkan, 2004) have reported that the managerial ownership is in negative relationship with agency cost and frim value.

The focal point of this study is to investigate the interdependence of capital stricture and cash holding decisions under the presence of different level of managerial ownership. For this purpose, data of 161 firms were collected form the annual reports of non-financial firms listed on Pakistan stock exchange over the period of five years from 2013 to 2017. The Leverage and level cash holdings are used as dependent variable while, MO, MO sqaure, and MO cube are used as independent. Whereas the variables including profitability, size, tangibility, growth bank debt, and liquidity as a control variable. The findings of this study are in line with the propositions of pecking order theory.

\section{Literature Review}

\subsection{Managerial Ownership in Pakistani Manufacturing Sector}

Table I presents the general picture of the ownership structure of non-financial firms listed in PSX. The largest shareholders of Pakistani firms are directors, other firms emerge as second and general public hold $8 \%$. The shares held by financial institutions are relatively low at just $18 \%$ and shows a decreasing trend. The average MO for Pakistani firms is $39 \%$ which is very high compared to $138 \mathrm{KSE}$ listed firms $22 \%$ (Basheer, 2014) and $155 \mathrm{KSE}$ Listed firms 29\% (Sheikh \& Wang, 2012) and more interestingly in 57\% firms managerial is between 40 to $100 \%$ (Figure 1).

Table 1. Yearly mean value of shareholding pattern

\begin{tabular}{lcccccc}
\hline Percentage of share held by & $\mathbf{2 0 1 3}$ & $\mathbf{2 0 1 4}$ & $\mathbf{2 0 1 5}$ & $\mathbf{2 0 1 6}$ & $\mathbf{2 0 1 7}$ & $\begin{array}{l}\text { Mean } \\
\text { N=5 }\end{array}$ \\
a. Directors & 35.00 & 35.00 & 36.00 & 37.00 & 38.00 & 36.00 \\
b. Financial Institutions & 20.00 & 19.00 & 18.00 & 17.00 & 16.00 & 18.00 \\
c. General Public & 16.00 & 16.00 & 17.00 & 17.00 & 17.00 & 16.00 \\
d. Other firms & 29.00 & 30.00 & 29.00 & 29.00 & 29.00 & 29.00 \\
*Grand Total & 100 & 100 & 100 & 100 & 100 & 100 \\
\hline
\end{tabular}


To present a clearer picture of MO, the author has drawn a graph measuring the annual change of a number of firms in different ownership percentage slabs $(0-10,11-20,21-30,31-40,40-50,50-70,70-100)$. On average 92.5 percent firm's managers hold $10 \%$ or more cash and in 46 percent of them hold $50 \%$ or more share. The Figure 1 highlighting an interesting fact that the number of firms with $\mathrm{MO}$ of 70 percent or more has increased significantly during the last three years whereas the number of firms in with MO of 50-70 percent has shown a decreasing trend.

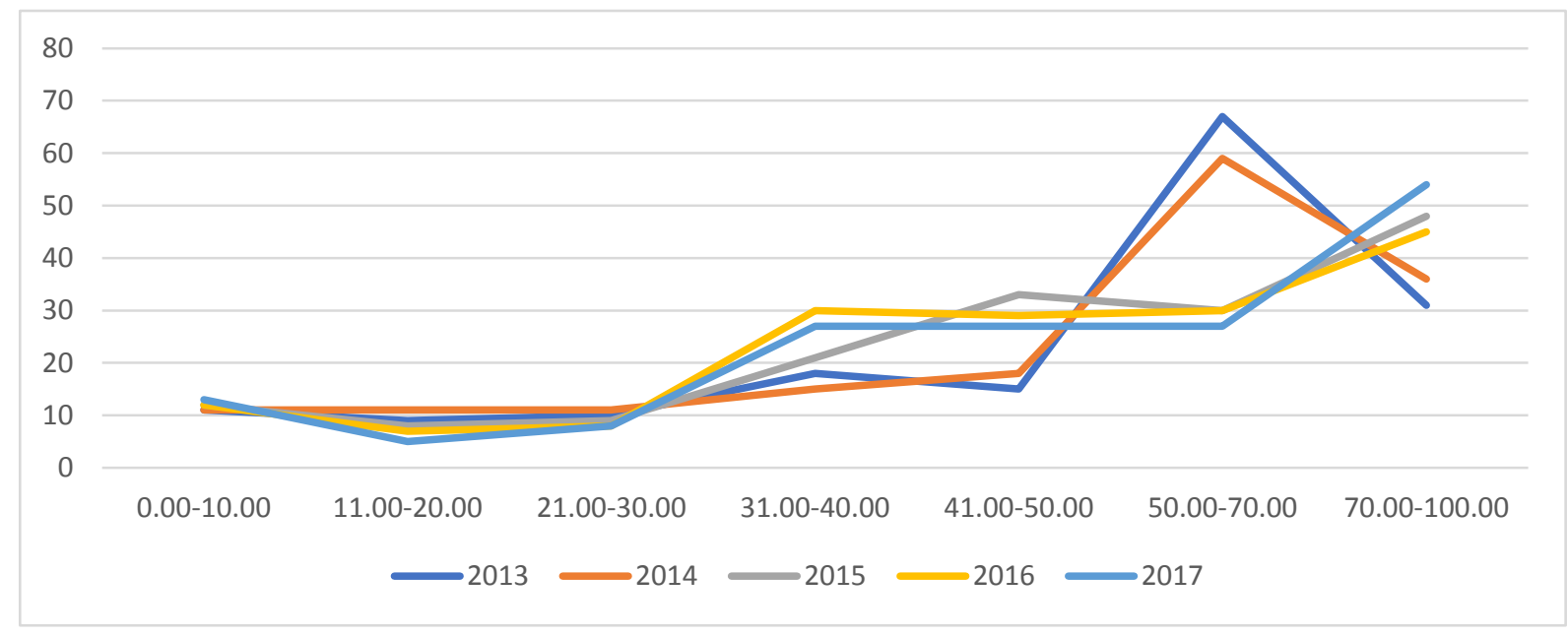

Figure 1

\subsection{MO and Corporate Financial and Cash Holding Decisions}

Managerial ownership is the percentage ownership of company's directors (Ozkan \&Ozkan, 2004; Basheer, 2014). According the Jensen and Meckling (1976), the misalignment of interest between owners and managers. Mnagers, who usually bear less cost and enjoy more benefits sometimes accept the project with lower NPV. Meanwhile, this misalignment of interest prevails in corporate decision making such cash holding decisions Fama \& Jensen, 1983; Ozkan \& Ozkan, 2004; Basheer, 2014; Mishra et al., 2017; Sheikh \& Wang, 2012; Akhtar et al., 2018). Cash holding has certain cost and benefits associated with it (Basheer, 2014). The cost associated with the higher level of cash holdings are the opportunity cost, whereas among the benefits of cash holdings is that it is cheapest and least risky source of finance. According to agency theory, the ownership of the company, considering the agency cost advice wants from manger to hold minimum amount of cash whereas. On the other hand, mangers, to exploit any future investment opportunity which may be lost because of accessing for finance prefer a higher level of cash reserves. This conflict of interest on the level of cash has significant impact on firm value. Fama and Jensen (1983) were the first who formally documented the issue of managerial opportunism and claim it as the main cause of agency problem. They further argued that MO inversely affects the managerial opportunism behavior. As mentioned above, the cash holding decisions are one of most important decisions of firms. Many prior researchers (Basheer, 2014; Rashid, 2016; Ozkan \& Ozkan, 2004; Dittmar et al., 2003; Opler et al., 1999) using different theoretical models have tried to explore the determinants of corporate cash holdings. The three widely used theoretical lenses used by researchers to explain the detriments of cash holdings are agency theory (Jensen \& Meckling, 1976; Jensen, 1986), Pecking order theory, and trade off theory (Kim, Mauer \& Sherman, 1998). When cash holding is explained by agency theory, it supports the lower level of cash holdings because of agency cost associated with it. Meanwhile it argues managerial ownership as a solution of agency cost.

According to the Jensen and Meckling (1976), the separation of the ownership and control is one of the main causes of the conflict of interest between owners and managers. Basheer et al. (2018) and Basheer et al. (2018) argue that the MO is which helps in aligning the interest of ownership and management. Ozkan and Ozkan (2004) have argued that managerial ownership is in non-linear relationship with cash holdings. In literature, the nonlinear relationship between entrenchment to alignment effect ((Najjar \& Clark, 2017; Basheer et al., 2014; Kusnadi, 2011: Basheer et al., 2018). These scholars have claimed that with the increasing ownership the alignment will increase, after certain level it will decrease i.e entrench and final again aligned. Therefore, we have drawn the following hypothesis

\section{H1: MO is a non-linear relationship with firm Cash holdings.}


Financing decisions are among few most debated topics of corporate finance. Financing decisions are carried out for many purposes. The agency theory presents two different but logical explanations about firms' debt financing. According to Jensen (1986), management of the company favors the debt financing as it increases the volume of assets under their control. This view also shows consistency with the argument that the debt financing can be seen as a proxy of firm growth. Therefore, managerial incentives will be levered with the debt financing (Sheikh \& Wang, 2012). In support of this view Brailsford et al. (2002) argued that the managerial entrenchment has significant impact on firm debt financing decisions. This incentive hypothesis offers a positive relationship between managerial ownership and firm capital structure decisions. On the other hand, another view of agency theory states that the increasing debt financing allow the owners to better monitor the performance of management. Meanwhile the increasing involvement of intuitional investors through debt financing offers more check than equity financing (Salehi et al., 2017). Therefore, this view offers a negative relationship between managerial ownership and firm capital structure decisions.

The prior study on the relationship between MO and capital structure offer no consensus. A group of studies (Friend \& Hasbrouck, 1988; Berger et al. 1997; Kim \& Sorensen, 1986; Bokpin S\& Arko 2009; Salehi et al., 2017; Wahyudin \& Solikhah, 2017; Ruan et al., 2009; Short, Zhang \& Keasey, 2002) found a positive relation between MO and capital structure and provide a support to the managerial incentive hypothesis According to Schleifer and Vishny (1997), a balanced blend of insider and outsider ownership is one of the major determinants of an effective code of corporate governance in Anglo American and European countries where ownership is not highly concentrated. Whereas, Young et al., (2008) argued that in developing counties where ownership is a highly concentrated code of corporate governance in form resemble the code of developed counties, however, in substance they differ. And in the presence of a weak code of corporate governance, the ownership concentration acts as a proxy for internal governance mechanism. Meanwhile, many prior studies (Ozkan \& Ozkan, 2004; Basheer, 2014) argued that $\mathrm{MO}$ offers a non-linear relationship with agency cost. So, on the basis of literature reviewed we have drawn the following hypothesis

\section{H2: MO is a non-linear relationship with firm capital Structure.}

The relationship between the managerial ownership and investment is usually explained with the two conflicting arguments which are termed as the incentive and entrenchment effect (Basher et al., 2018). The incentive argument explains appositive and significant relationship between the managerial ownership and investment decisions. Bernstein et al., (2010) argued that when the managerial ownership increases their incentives in the projects with positive NPVs increase and ultimately, they prefer investment. On the other hand, the entrenchment view argues the negative relationship between managerial ownership and investment. Matzler et al. (2015) argued that the being owner sometimes managers behave more risk averse and stop investing in projects. They continued and argued that there is phenomena of interest alignment and misalignment means the relationship turns from negative to positive or from positive to negative as the managerial ownership changes. Therefore, it is hypothesized that

\section{H3: MO is a non-linear relationship with Investment.}

\subsection{Corporate Cash Holdings, Investmnet and Capital Structure}

The empirical studies on the relationship between capital structure decisions and cash holding decisions offer mix results. Jensen and Meckling (1976) in their vintage paper argued that entrenched mangers to peruse self-interest prefer large amount of cash which increase the agency cost. In this case, leverage could be used to mitigate agency problems. Therefore, leverage would influence cash holdings negatively as companies might use debt to reduce agency problems associated with cash holdings (John, 1993). In line with this, Kim et al. (1998) and Ferrira and Vilela (2004) state that leverage and cash holdings are negatively related.On the other hand, firms tend to hold excess cash to avoid information asymmetric problems from using external financing that might cause financial distress and bankruptcy cost (Faulkender, 2004). Graham and Harvey (2001) and Al-Najjar, (2015) found that leverage is negatively influenced by cash holdings. Further, Garcia-Teruel and Martinez-Solano (2008) state that excess cash could lead to lower financial distress and bankruptcy cost. This allows a company to use more debt. The authors find that cash holdings affect leverage positively. Williamson (1988) also finds a positive relationship between cash holdings and firms leverage

Myers and Majluf (1984) argue that firms hold excess cash balances because cash offers lower financing costs for firms and it permits them to undertake valuable investment opportunities when arise. Shleifer and Vishny (1992) state that when firms hold higher cash level this could reduce the financial distress cost. Moreover, Faulkender (2004) argue that high information asymmetric make cash holdings necessary for the firms to avoid the high cost of external financing. Graham and Harvey (2001) find that leverage affect cash holding negatively implying that firms could 
reach the financial flexibility by holding a large amount of cash and low leverage. Ozkan and Ozkan (2004) also find the effect of cash holding is negative on leverage. Therefore, holding appropriate cash level is an important decision for managers to ensure survivability of the firm. In this case, the amount of cash holdings helps to explain leverage levels. Prior researchers (Halling, Yu \& Zechner, 2016; Alan \& Gaur, 2018: Serrasqueiro, 2017; Aivazian et al., 2005; Ridha \& Bajka, 2010; Bassey et al., 2017) have argued that financing is directly linked with the investment as financial decisions are normalcy compelled with the investment. There is also view It is argued that the lowering the level of debt will mitigate the bankrupt risk and ultimately provides incentives for investment. Therefore, in line with theory we have developed the following hypotheses:

\section{H4: Financing decision affects investment decision.}

\section{H5: Investment decision affects financing decision.}

\section{H6: Cash holdings decisions affect financing decisions}

\section{Data and Methodology}

\subsection{Data Source}

The balance panel of 161 nonfinancial firm listed on PSX over the period of five years from 2013 to 2017 is used to achieve the research objectives. Polled OLS, Fixed effect and Random effect estimates are employed to answer the reach questions. The definition of variables used in this study are adopted from previous studies and are given in Table 2.

Table 2

\begin{tabular}{lll}
\hline \multicolumn{1}{c}{ Variable } & Proxy & Definition \\
\hline Cash & Cash & (Total cash + Cash Equivalent)/ Total Asset \\
\hline Leverage & Leverage & Total debt /Total asset \\
\hline Investment & INV & $\begin{array}{l}\text { Market-to-book ratio (MTBV). Net investment divided by } \\
\text { last period's gross fixed assets }\end{array}$ \\
\hline Cash Flow & Cflow & $\begin{array}{l}\text { Cash Flow*/ Total asset. } \\
\text { *Cash flow is calculated by adding up depreiciation and } \\
\text { income before tax }\end{array}$ \\
\hline Profitability & Prof & Profit after tax to total assets \\
\hline Tangibility & Teng & A fixed asset to total assets \\
\hline Variability & Var & Standard Deviation of Cash Flows/Total Asset \\
\hline Dividend & Dividend & Dividend payment/Total Asset \\
\hline & Man & \% of equity held by directors. \\
\cline { 2 - 3 } & Mans * & Square of MO \\
\cline { 2 - 3 } Oanagerial & Manc & Cube of MO \\
\hline
\end{tabular}

*Omitted to resolve multicollinearity issue

\subsection{Model Specification}

The prime objective of the current study is to investigate the interdepended of financial decision. In addition to that the impact of different level of managerial ownership on the interdepended of financial decisions is also examined 
agency theory, pecking order theory and the signaling theory are used as the theoretical lenses to draw the theocratical framework. To achieve the objective the following econometric models are drawn

$$
\begin{aligned}
& \text { Cash }_{i t}=\alpha_{0}+\alpha_{1} \text { Leverage }_{i t}+\alpha_{2} \text { Man }_{i t+} \alpha_{3} \text { Manc }+\alpha_{4} \text { Investmnet }_{i t}+\alpha_{5} \text { Prof }_{i t}+\alpha_{6} \text { Dividend }_{i t}+\alpha_{7} \text { Var }_{i t}+ \\
& \alpha_{8} \text { Teng }_{i t}+\alpha_{9} M b r_{i t}+\alpha_{10} \text { cflow } \text { flt }+\varepsilon_{i t} \\
& \text { Leverage }_{i t}=\alpha_{0}+\alpha_{1} \text { Cash }_{i t}+\alpha_{2} \text { Man }_{i t} \alpha_{3} \text { Manc }+\alpha_{4} \text { Investmnet }_{i t}+\alpha_{5} \text { Prof }_{i t}+\alpha_{6} \text { Dividend }_{i t}+\alpha_{7} \text { Var }_{i t}+ \\
& \alpha_{8} \text { Teng }_{i t}+\alpha_{9} M_{\text {brit }}+\alpha_{10} \text { cflow }_{i t}+\varepsilon_{i t} \\
& \text { Investmnet }_{i t}=\alpha_{0}+\alpha_{1} \text { Cash }_{i t}+\alpha_{2} \text { Man }_{i t+} \alpha_{3} \text { Manc }++\alpha_{4} \text { Leverage }_{i t}+\alpha_{5} \text { Prof }_{i t}+\alpha_{6} \text { Dividend }_{i t}+ \\
& \alpha_{7} \text { Var }_{i t}+\alpha_{8} \text { Teng }_{i t}+\alpha_{9} \text { Mbr }_{i t}+\alpha_{10} \text { cflow } \text { flt }_{i t}+\varepsilon_{i t}
\end{aligned}
$$

\subsection{Pre-test Specifications}

In the panel data econometric analysis, there are three main models: pooled OLS model, FE model, and RE model. A key difference between them lies in the treatment of $\alpha i$, which goes by different names such as individual effects, individual heterogeneity, unobserved effects, etc. In the pooled OLS model, $\alpha \mathrm{i}$ is assumed to be absent. If $\alpha \mathrm{i}$ is present, then either the FE model or the RE model is appropriate. The choice between them hinges on whether $\alpha \mathrm{i}$ is correlated with other regressors in the model. If there is such a correlation, then the FE model is appropriate. If there is no such correlation, then the RE model is appropriate (Wooldridge, 2006). Breusch-Pagan (BP) test and Wooldridge test and the Hausman specification are used to decides between polled OLS, fixed effect and random effect estimates

\section{Data Analysis and Research Findings}

\subsection{Descriptive Analysis}

The descriptive statistics of the variable used in the study is shown in the Table 3.

Table 3. Descriptive statistics

\begin{tabular}{lccccc}
\hline & N & Minimum & Maximum & Mean & Std. Deviation \\
\hline Cash & 805 & 0.00006 & 0.19368 & 0.0131 & 0.019 \\
Investment & 805 & 0.00000 & 15.25691 & 0.6314 & 1.322 \\
Leverage & 805 & 0.06719 & 0.99769 & 0.6048 & 0.188 \\
Man & 805 & 0.00091 & 0.98963 & 0.4590 & 0.263 \\
Manc & 805 & 0.00000 & 0.96923 & 0.1918 & 0.225 \\
Prof & 805 & -0.37689 & 0.29285 & 0.0282 & 0.083 \\
Dividend & 805 & -0.01440 & 0.27669 & 0.0064 & 0.018 \\
Var & 805 & 0.00022 & 1.26226 & 0.1526 & 0.188 \\
Teng & 805 & 0.23854 & 0.99975 & 0.5999 & 1.65 \\
Mbr & 805 & 0.00000 & 15.25691 & 0.6314 & 1.322 \\
Cflow & 805 & 0.44568 & 0.92172 & 0.0923 & 0.134 \\
\hline Valid N (listwise) & 805 & & & & \\
\hline
\end{tabular}

\subsection{Correlation Analysis}

To examine the strength of the relationship between the variables we have employed the Pearson correlation. Meanwhile, it is also employed to identify the variables which can cause the multilinearity issue. The Table 3 revealed the fact that there is no multicollinearity issue and the variables are correlated at the significant level. The 0.89 is the highest correlation which is observed between the MO at higher level and the MO at lower level. 
Table 4. Correlation analysis

\begin{tabular}{|c|c|c|c|c|c|c|c|c|c|c|}
\hline & Cash & Leverage & Mans & Manc & Prof & Dividend & Var & Teng & Mbr & Cflow \\
\hline Cash & 1 & & & & & & & & & \\
\hline Leverage & -0.2830 & 1 & & & & & & & & \\
\hline Man & -0.0357 & 0.1453 & 1 & & & & & & & \\
\hline Manc & -0.0910 & 0.1288 & 0.7929 & 1 & & & & & & \\
\hline Prof & 0.2456 & -0.3363 & 0.2129 & 0.0579 & 1 & & & & & \\
\hline Dividend & 0.1308 & -0.2547 & -0.0828 & -0.0474 & 0.0882 & 1 & & & & \\
\hline Var & -0.0220 & 0.2994 & -0.1216 & -0.0935 & -0.3391 & -0.0720 & 1 & & & \\
\hline Teng & -0.1095 & 0.1030 & -00027 & 0.0334 & -0.2807 & -0.2236 & 0.3642 & 1 & & \\
\hline Investment & -0.0342 & 0.0292 & -0.1009 & -0.0538 & -0.1771 & 0.1142 & 0.1906 & 0.1061 & 1 & \\
\hline Cflow & 0.0604 & -0.2966 & 0.0367 & -0.0288 & 0.5245 & 0.0672 & -0.1263 & -0.1620 & -0.1484 & 1 \\
\hline
\end{tabular}

\subsection{The Corporate Cash Decision Model}

We have started our analysis with the Pooled OLS, However, Breusch-Pagan (BP) which have the chi-square value of 15.63 and $p$ value significant at 0 percent that there is an issue of autocorrelation in OLS model. Meanwhile, the finding of Wooldridge test test (f-value $=11.92$ at 0.000 ) highlights the issue of heteroscedasticity. Thus, the existence heteroscedasticity and autocorrelation highlight the robust standard error in pooled OLS. Meanwhile, In order to conclude that the results are clear from the problem of multicollinearity, the variance inflation factor (VIF) values are examined. VIF values of more than 10 are considered to suffer from multicollinearity problem (Tu, Kellet, Clerehugh \& Gilithorpe, 2005). Therefore, fixed effects estimates are chosen over pooled OLS. Finally, the Hausman test is performed to compare FE model with RE model. The Hausman test shows that the random effect model is the appropriate model since the Hausman test produces a chi-square of 8.18 with a p-value of 0.515 . Therefore, random effects technique is chosen over fixed effects technique. The outcomes of the fixed effect, random effect and pooled OLS estimates are shown in the Table 5.

The relationship of financing, investment and managerial ownership at higher level with the corporate cash holdings are negative and significant. Whereas the lower level of managerial ownership variability in cash flows and the profitability are in positive relationship with the corproate 3 cash holdings

The MO is in a negative relationship with corporate cash holdings which indicates that the cash holding level of firm decreases as the stakes of managers in the firm increase. The results are consistent with the proposition of agency theory which argues that higher level of MO helps in aligning the interest of management and shareholders. The results are consistent with the prior findings of Basheer (2014) and Ozkan and Ozkan (2004).

The relationship between capital structure and cash holding is negative which provide support to pecking order theory and. Pecking order theory argue that company prioritise their internally generated first to finance their projects. Therefore the companies with a higher level of cash retained to invest their projects.

Table 5. Regression results of financing model

\begin{tabular}{lccc}
\hline Dependent Variable:CASH & $\begin{array}{c}\text { Pooled OLS } \\
\text { Coefficient } \\
\text { (p-value) }\end{array}$ & $\begin{array}{c}\text { Fixed Effect } \\
\text { Coefficient } \\
\text { (p-value) }\end{array}$ & $\begin{array}{c}\text { Random Effect } \\
\text { Coefficient } \\
\text { (p-value) }\end{array}$ \\
\hline Leveage & $-0.0177^{* * *}$ & -0.0005 & -0.0089 \\
Man & $(0.010)$ & $(0.953)$ & $(0.244)$ \\
Manc & $0.0198^{* *}$ & 0.0154 & 0.0170 \\
& $(0.027)$ & $(0.395)$ & $(0.149)$ \\
& $-0.0254^{* *}$ & -0.0238 & $-0.0243^{*}$ \\
& $(0.014)$ & $(0.228)$ & $(0.071)$
\end{tabular}




$\begin{array}{lccc}\text { Prof } & 0.0222 & -0.0313^{*} & 0.0284^{*} \\ & (0.176) & (0.074) & (0.075) \\ \text { Div } & 0.0797 & -0.0488 & 0.0633 \\ & (0.183) & (0.394) & (0.248) \\ \text { Var } & 0.0102^{*} & 0.0226 & 0.0108 \\ & (0.108) & (0.203) & (0.227) \\ \text { Teng } & 0.0099 & -0.0044 & -0.0049 \\ & (0.160) & (0.679) & (0.553) \\ \text { Investment } & -0.0004 & -0.0001 & -0.0002 \\ & (0.579) & (0.888) & (0.797) \\ \text { Cflow } & -0.0097 & 0.0147 & 0.0155 \\ & (0.286) & (0.238) & (0.864) \\ \boldsymbol{R}^{\wedge} \mathbf{2} & 0.0740 & 0.018 & 0.06 \\ \text { Number of firms } & 161 & 161 & 161\end{array}$

* Significant at the $10 \%$ level, $* *$ Significant at the 5\% level, and *** Significant at the $1 \%$ level

\subsection{The Financing Decision Model Decision Model}

The analysis is started with the Pooled OLS, However, Breusch-Pagan (BP) which have the chi-square value of 36.96 and a p-value of 0 . percent that there is an issue of autocorrelation in OLS model. Meanwhile, the finding of Wooldridge test test (f-value $=59.125$ at 0.000 ) highlights the issue of heteroscedasticity. Thus, the existence heteroscedasticity and autocorrelation highlight the robust standard error in pooled OLS. Meanwhile, in order to conclude that the results are clear from the problem of multicollinearity, the variance inflation factor (VIF) values are examined. VIF values of more than 10 are considered to suffer from multicollinearity problem (Tu, Kellet, Clerehugh \& Gilithorpe, 2005). The Hausman test is used to decide between the fixed effect and random effect estimates. The findings of the Hausman test (chi-square of 36.96 at p-value of 0.00) declares the fixed effect as the most appropriate estimates

In equation 2 the lower level of MO and variability of cash flow are in positive relation while a higher level of MO profitability, dividend, tangibility market to book ratio and cash flow is in negative relation with capital structure. Whereas profitability, variability, and tangibility are in significant relation with capital structure. The MO is in nonlinear relation with capital structure decision. This provides support to the proposition of agency theory which states that debt act as a shareholder check on managers and helps in strengthening the internal governance mechanism. Therefore, Pakistani listed firms with higher level of ownership are avoiding a higher level of debt.

Table 6. Regression results of financing model

\begin{tabular}{|c|c|c|c|}
\hline Dependent Variable:Leverage & $\begin{array}{c}\text { Pooled OLS } \\
\text { Coefficient } \\
\text { (p-value) }\end{array}$ & $\begin{array}{l}\text { Fixed Effect } \\
\text { Coefficient } \\
\text { (p-value) }\end{array}$ & $\begin{array}{c}\text { Random Effect } \\
\text { Coefficient } \\
\text { (p-value) }\end{array}$ \\
\hline Cash & $\begin{array}{l}-1.089 * * * \\
(0.010)\end{array}$ & $\begin{array}{l}-0.020 \\
(0.953)\end{array}$ & $\begin{array}{l}-0.211 \\
(0.541)\end{array}$ \\
\hline Man & $\begin{array}{l}0.256 * * * \\
(0.000)\end{array}$ & $\begin{array}{l}0.051 \\
(0.628)\end{array}$ & $\begin{array}{c}0.182 * * \\
(0.037)\end{array}$ \\
\hline Manc & $\begin{array}{l}-0.154^{*} \\
(0.059)\end{array}$ & $\begin{array}{l}-0.176 \\
(0.130)\end{array}$ & $\begin{array}{l}-0.174 * \\
(0.076)\end{array}$ \\
\hline Prof & $\begin{array}{c}--0.756^{* * *} \\
(0.176)\end{array}$ & $\begin{array}{l}-0.661 * * * \\
(0.000)\end{array}$ & $\begin{array}{c}-0.697 * * * \\
(0.000)\end{array}$ \\
\hline Div & $\begin{array}{c}-2.311 * * * \\
(0.000)\end{array}$ & $\begin{array}{c}-0.460 \\
(0.174)\end{array}$ & $\begin{array}{c}-0.794 * * \\
(0.021)\end{array}$ \\
\hline
\end{tabular}




$\begin{array}{lccc}\text { Var } & 0.238^{* * *} & 0.493^{* * *} & 0.331^{* * *} \\ \text { Teng } & (0.000) & (0.000) & (0.000) \\ & -0.171^{* *} & -0.211^{* * *} & -0.190^{* * *} \\ \text { Investmnet } & (0.002) & (0.001) & (0.001) \\ & -0.004 & -0.009 & -0.005 \\ \text { Cflow } & (0.528) & (0.164) & (0.389) \\ & -0.161^{* *} & -0.098 & -0.110 \\ \boldsymbol{R}^{\wedge} \mathbf{2} & (0.024) & (0.1 .81) & (0.113) \\ \text { Number of firms } & 0.352 & 0.168 & 0.277 \\ \end{array}$

* Significant at the $10 \%$ level, ** Significant at the 5\% level, and *** Significant at the $1 \%$ level

\subsection{The Investment Decision Model}

We have started our analysis with the Pooled OLS, However, Breusch-Pagan (BP) which have the chi-square value of 34.96 and $p$ value significant at 0 percent that there is an issue of autocorrelation in OLS model. Meanwhile, the finding of Wooldridge test test (f-value $=53.225$ at 0.000 ) highlights the issue of heteroscedasticity. Thus, the existence heteroscedasticity and autocorrelation highlight the robust standard error in pooled OLS.

Meanwhile, in order to conclude that the results are clear from the problem of multicollinearity, the variance inflation factor (VIF) values are examined. VIF values of more than 10 are considered to suffer from multicollinearity problem (Tu, Kellet, Clerehugh \& Gilithorpe, 2005). Therefore, fixed effects estimates are chosen over pooled OLS. The Hausman test is used to decide between the fixed effect and random effect estimates. The findings of the Hausman test (chi-square of 34.96 at p-value of 0.00) declares the fixed effect as the most appropriate estimates

In equation 3 the higher level of MO and variability of cash flow and profitability are in positive relation while a lower level of MO, dividend, tangibility market to book ratio and cash flow is in negative relation with capital structure. Whereas profitability, variability, and tangibility are in significant relation with capital structure. The MO is in nonlinear relation with investment decisions. This provides support to the proposition of agency theory which states that debt act as a shareholder check on managers and helps in strengthening the internal governance mechanism. Therefore, Pakistani listed firms with higher level of ownership believe in higher level of investments.

Table 7. Regression results of investment model

\begin{tabular}{lccc}
\hline Dependent Variable:MBR & $\begin{array}{c}\text { Pooled OLS } \\
\text { Coefficient } \\
\text { (p-value) }\end{array}$ & $\begin{array}{c}\text { Fixed Effect } \\
\text { Coefficient } \\
\text { (p-value) }\end{array}$ & $\begin{array}{c}\text { Random Effect } \\
\text { Coefficient } \\
\text { (p-value) }\end{array}$ \\
\hline Cash & $-0.389^{* * *}$ & $-0.040^{*}$ & -0.321 \\
Man & $(0.010)$ & $(0.080)$ & $(0.541)$ \\
Manc & $-0.256^{* * *}$ & -0.043 & $-0.283^{* *}$ \\
Leveage & $(0.000)$ & $(0.345)$ & $(0.027)$ \\
Prof & $0.234^{*}$ & 0.156 & $0.134^{*}$ \\
Div & $(0.059)$ & $(0.130)$ & $(0.076)$ \\
& $0.0327^{* * *}$ & $0.015^{* *}$ & 0.069 \\
Var & $(0.010)$ & $(0.050)$ & $(0.244)$ \\
& $0.457^{* * *}$ & $0.551^{* * *}$ & $0.437^{* * *}$ \\
& $(0.176)$ & $(0.000)$ & $-0.000)$ \\
& $-0.351^{* * *}$ & -0.530 & $-0.684^{* *}$ \\
& $(0.000)$ & $(0.174)$ & $0.021)$ \\
& $0.238^{* * *}$ & $0.493^{* * *}$ & $0.541^{* * *}$
\end{tabular}




\begin{tabular}{lccc} 
Teng & $-0.271^{* *}$ & $-0.321^{* * *}$ & $-0.278^{* * *}$ \\
& $(0.002)$ & $(0.001)$ & $(0.001)$ \\
Cflow & $-0.161^{* *}$ & -0.098 & -0.110 \\
& $(0.024)$ & $(0.1 .81)$ & $(0.113)$ \\
$\boldsymbol{R}^{\wedge} \mathbf{2}$ & 0.352 & 0.168 & 0.277 \\
Number of firms & 161 & 161 & 161 \\
\hline
\end{tabular}

\section{Conclusion}

The current paper contributes to extending the scope of finance and accounting and Finance literature. It provides an additional insight into the influence of corporate governance mechanisms on cash holdings, investment and financial leverage decisions on listed companies operating in the listed industry of Pakistan. This research investigates the simultaneous effect of leverage on cash holdings, a large amount of cash leads to higher agency cost and lower return and one way to reduce agency cost is through the optimal amount of leverage. However, holding a large amount of debt might increase the risk of costly bankruptcy. This problem could be mitigated by using the optimal amount of cash. In addition to that as most of the listed firms in Pakistan are being controlled by insiders. Therefore, by conducting such a study in listed sector of Pakistan with its unique institutional settings would add to the understanding of leverage and cash holdings policies in an emerging market. The focal point of this study is to investigate the interdependence of capital structure and cash holding decisions under the presence of different level of managerial ownership. For this purpose, data of 161 firms were collected form the annual reports of non-financial firms listed on Pakistan stock exchange over the period of five years from 2013 to 2017. The Leverage and level cash holdings are used as dependent variable while, MO, MO sqaure, and MO cube are used as independent. Whereas the variables including profitability, size, tangibility, growth bank debt, and liquidity as a control variable. The findings of this study are in line with the propositions of pecking order theory. The largest shareholders of Pakistani firms are directors, other firms emerge as second and general public hold $8 \%$. The share held by financial institutions are relatively low at just $18 \%$ and shows a decreasing trend. The average MO for Pakistani firms is $39 \%$ which is very high compared to $138 \mathrm{KSE}$ listed firms $22 \%$ (Basheer, 2014) and $155 \mathrm{KSE}$ Listed firms $29 \%$ (Sheikh \& Wang, 2012) and more interestingly in $57 \%$ firms managerial is between 40 to $100 \%$. The balance panel of 161 nonfinancial firm over the period of five years from 2013 to 2017 is used to achieve the research objectives. Polled OLS, Fixed effect and Random effect estimates are employed to answer the reach questions

The managerial ownership with an average mean ownership of 39 is appeared at the top. Interestingly more than 75 percent firms are being controlled by mangers and in more than 60 percent firms of our sample the controlling managers hold more than 40 percent of shares. The Wu Hausman test is performed to determine the existence of the endogeneity problem. The results indicate that the financial decisions namely cash holding decisions, financing decisions and investment decisions has significant impact on each other. Where the managerial ownership is in nonlinear relationship with financial decisions. The results of the study are also providing support to agency theory, pecking order theory and the signaling theory

The study will be helpful for policymakers, researchers, corporate personals and financial institutions in understanding the interrelationship between financing decisions and the role of managerial ownership in there interdepended. The study is among the pioneering studies on the issue and will provide policy guideline on the said issues

\section{References}

Ahmed Sheikh, N., \& Wang, Z. (2012). Effects of corporate governance on capital structure: empirical evidence from Pakistan. Corporate Governance: The International Journal of Business in Society, 12(5), 629-641. https://doi.org/10.1108/14720701211275569

Aivazian, V. A., Ge, Y., \& Qiu, J. (2005). The impact of leverage on firm investment: Canadian evidence. Journal of Corporate Finance, 11(1-2), 277-291. https://doi.org/10.1016/S0929-1199(03)00062-2

Akhtar, T., Tareq, M. A., Sakti, M. R. P., \& Khan, A. A. (2018). Corporate governance and cash holdings: the way forward. Qualitative Research in Financial Markets, 10(2), 152-170. https://doi.org/10.1108/QRFM-04-2017-0034

Alan, Y., \& Gaur, V. (2018).Operational investment and capital structure under asset-based lending. Manufacturing \& Service Operations Management. https://doi.org/10.1287/msom.2017.0670 
Ali, K., Khan, Z., Khan, N., Alsubaie, A. H. I., Subhan, F., \& Kanadil, M. (2016). Performance Evaluation of UK Acquiring Companies in the Pre and Post-Acquisitions Periods. Asian Journal of Economics and Empirical Research, 3(2), 130-138. https://doi.org/10.20448/journal.501/2016.3.2/501.2.130.138

Ali, M. (2018). Determinants and consequences of board size: conditional indirect effects. Corporate Governance: The International Journal of Business in Society, 18(1), 165-184. https://doi.org/10.1108/CG-01-2016-0011

Al-Najjar, B., \& Clark, E. (2017). Corporate governance and cash holdings in MENA: evidence from internal and external governance practices. Research in International Business and Finance, 39, 1-12. https://doi.org/10.1016/j.ribaf.2016.07.030

Basheer, M. F. (2014). Impact of Corporate Governance on Corporate Cash Holdings: An empirical study of firms in manufacturing industry of Pakistan. International Journal of Innovation and Applied Studies, 7(4), 1371.

Basheer, M. F., Khan, S., Hassan, S. G., \& Shah, M. H. (2018). The Corporate Governance andÂ Interdependence of Investment and Financing Decisions of Non-Financial Firms in Pakistan. The Journal of Social Sciences Research, 316-323. https://doi.org/10.32861/jssr.spi5.316.323

Basheer, M. F., Waemustafa, W., \& Ahmad, A. A. (2018). The Paradox of Managerial Ownership and Financial Decisions of the Textile Sector: An Asian Market Perspective. The Journal of Social Sciences Research, 184-190. https://doi.org/10.32861/jssr.spi4.184.190

Bassey, N. E., Arene, C. J., \& Okpukpara, B. C. (2014). Determinants of capital structure of listed agro firms in Nigeria. Economic Affairs, 59(1), 35. https://doi.org/10.5958/j.0976-4666.59.1.004

Bernstein, S., Lerner, J., Sorensen, M., \& Strömberg, P. (2010). Private equity, industry performance and cyclicality. Globalization of Alternative Investments, 3, 3-24. https://doi.org/10.3386/w15632

Boateng, A., Cai, H., Borgia, D., Gang Bi, X., \& Ngwu, F. N. (2017). The influence of internal corporate governance mechanisms on capital structure decisions of Chinese listed firms. Review of Accounting and Finance, 16(4), 444-461. https://doi.org/10.1108/RAF-12-2015-0193

Bollazzi, F., \& Risalvato, G. (2018). Corporate Responsibility and ROA: Evidence from the Italian Stock Exchange. Asian Economic and Financial Review, 8(4), 565-570. https://doi.org/10.18488/journal.aefr.2018.84.565.570

Chakraborty, I. (2018). Effects of Ownership Structure on Capital Structure of Indian Listed Firms: Role of Business Groups Vis-A-Vis Stand-Alone Firms. Emerging Markets Finance and Trade. https://doi.org/10.1080/1540496X.2018.1434071

Chang'ach, J. K. (2018). An Historical Trajectory of the Economic Transformation of the Southern Keiyo Community in Kenya. Global Journal of Social Sciences Studies, 4(2), 52-69. https://doi.org/10.20448/807.4.2.52.69

Chen, V. Z., Musacchio, A., \& Li, S. (2018). A Principals-Principals Perspective of Hybrid Leviathans: Cross-Border Acquisitions by State-Owned MNEs. Journal of Management. https://doi.org/10.1177/0149206318764293

Chevalier, J. (2004). What Do We Know About Cross-subsidization? Evidence from Merging Firms. Advances in Economic Analysis \& Policy, 4(1). https://doi.org/10.2202/1538-0637.1218

Chidoko, C., \& Mashavira, N. (2014). An analysis of corporate governance in the banking sector of Zimbabwe. Humanities and Social Sciences Letters, 2(3), 174-180.

Childs, P. D., Mauer, D. C., \& Ott, S. H. (2005). Interactions of corporate financing and investment decisions: The effects of agency conflicts. Journal of financial economics, 76(3), 667-690. https://doi.org/10.1016/j.jfineco.2004.06.012

Cohen, J., Holder-Webb, L., \& Khalil, S. (2017). A further examination of the impact of corporate social responsibility and governance on investment decisions. Journal of Business Ethics, 146(1), 203-218. https://doi.org/10.1007/s10551-015-2933-5

Detthamrong, U., Chancharat, N., \& Vithessonthi, C. (2017). Corporate governance, capital structure and firm performance: evidence from Thailand. Research in International Business and Finance, 42, 689-709. https://doi.org/10.1016/j.ribaf.2017.07.011

Ekpung, E. G. (2014). Public infrastructure spending and economic growth in Nigeria: An Error Correction Mechanism (ECM) approach. Journal of Social Economics Research, 1(7), 129-140. 
Eshiet, U. E. (2017). Implications of Accountants Unethical Behavior and Corporate Failures. International Journal of Business, Economics and Management, 4(4), 82-94. https://doi.org/10.18488/journal.62.2017.44.82.94

Faccio, M., Morck, R., \& Yavuz, M. D. (2018). Business Groups and Firm-Specific Stock Returns. https://doi.org/10.2139/ssrn.3167489

Halling, M., Yu, J., \& Zechner, J. (2016). Leverage dynamics over the business cycle. Journal of Financial Economics, 122(1), 21-41. https://doi.org/10.1016/j.jfineco.2016.07.001

Hasan, A., \& Butt, S. A. (2009). Impact of Ownership Structure and Corporate Governance on Capital Structure of Pakistani Listed Companies. International Journal of Business and Management. https://doi.org/10.5539/ijbm.v4n2p50

Heyden, M. L., Kavadis, N., \& Neuman, Q. (2017). External corporate governance and strategic investment behaviors of target CEOs. Journal of Management, 43(7), 2065-2089. https://doi.org/10.1177/0149206314563400

Iqbal, M., \& Javed, F. (2017). The Moderating Role of Corporate Governance on the Relationship between Capital Structure and Financial Performance: Evidence from Manufacturing Sector of Pakistan. International Journal of Research in Business and Social Science, 6(1), 89. https://doi.org/10.20525/ijrbs.v6i1.624

Jensen, M. C. (1986). Agency costs of free cash flow, corporate finance, and takeovers. The American Economic Review, 76(2), 323-329.

Jensen, M. C., \& Meckling, W. H. (1976). Theory of the firm: Managerial behavior, agency costs and ownership structure. Journal of Financial Economics, 3(4), 305-360. https://doi.org/10.1016/0304-405X(76)90026-X

Khan, H., Hassan, R., \& Marimuthu, M. (2017). Diversity on Corporate Boards and Firm Performance: An Empirical Evidence from Malaysia. American Journal of Social Sciences and Humanities, 2(1), 1-8. https://doi.org/10.20448/801.21.1.8

Kimengsi, J. N., \& Gwan, S. A. (2017). Reflections on Decentralization, Community Empowerment and Sustainable Development in Cameroon. International Journal of Emerging Trends in Social Sciences, 1(2), 53-60. https://doi.org/10.20448/2001.12.53.60

Liew, C., Alfan, E., \& Devi, S. (2017). Family firms, expropriation and firm value: Evidence of the role of independent directors' tenure in Malaysia.

Lipton, M., \& Lorsch, J. W. (1992). A modest proposal for improved corporate governance. The Business Lawyer, 59-77.

Matzler, K., Veider, V., Hautz, J., \& Stadler, C. (2015). The impact of family ownership, management, and governance on innovation. Journal of Product Innovation Management, 32(3), 319-333. https://doi.org/10.1111/jpim.12202

Mejdoub, H., \& Arab, M. B. (2017). A Multivariate Analysis for Risk Capital Estimation in Insurance Industry: Vine Copulas. Asian Development Policy Review, https://doi.org/10.18488/journal.107.2017.52.100.119

Mutlu, C. C., van Essen, M., Peng, M. W., Saleh, S. F., \& Duran, P. (2017). Corporate Governance in China: A Meta - Analysis. Journal of Management Studies. https://doi.org/10.1111/joms.12331

Myers, S. C. (1977). Determinants of corporate borrowing. Journal of Financial Economics, 5(2), 147-175. https://doi.org/10.1016/0304-405X(77)90015-0

Nor, N. H. M., Nawawi, A., \& Salin, A. S. A. P. (2017). The Influence of Board Independence, Board Size and Managerial Ownership on Firm Investment Efficiency. Pertanika Journal of Social Sciences \& Humanities, 25(3).

Oitsile, B., Galebotswe, O., \& Sekwati, L. (2018). Insurance-Economic Growth Nexus: Evidence from Botswana. Asian Economic and Financial Review, 8(6), 843-852. https://doi.org/10.18488/journal.aefr.2018.86.843.852

Okon, E. O., \& Monday, O. I. (2017). Empirical and Evidence-Based Investigation: External Debt, Poverty and Economic Growth Nexus. International Journal of Applied Economics, Finance and Accounting, 1(1), 37-47. https://doi.org/10.33094/8.2017.11.37.47

Omodero, C. O., \& Ogbonnaya, A. K. (2018). Corporate Tax and Profitability of Deposit Money Banks in Nigeria. Journal of Accounting, Business and Finance Research, 3(2), 47-55. https://doi.org/10.20448/2002.32.47.55 
Ozkan, A., \& Ozkan, N. (2004). Corporate cash holdings: An empirical investigation of UK companies. Journal of Banking \& Finance, 28(9), 2103-2134. https://doi.org/10.1016/j.jbankfin.2003.08.003

Razek, M. A. (2014). The Association Between Corporate Risk Disclosure and Firm Performance in Emerging Country-The Case of Egypt. Journal of Empirical Studies, 1(3), 105-115.

Ridha, M., \& Bajka, D. (2010). The Impact of R\&D Investments on the Capital Structure of Swedish Public Life Science Companies.

Romli, A. A. N., \& Ismail, S. (2014). Quality Management Practices towards Customer Satisfaction in Local Authority Public Services Website. International Journal of Public Policy and Administration Research, 1(3), 80-93.

Ruan, W., Tian, G., \& Ma, S. (2009). Managerial Ownership and Firm Value: Evidence From China's Civilian-Run-Firms. Journal of Accounting and Finance.

Salehi, M., Lotfi, A., \& Farhangdoust, S. (2017). The effect of financial distress costs on ownership structure and debt policy: An application of simultaneous equations in Iran. Journal of Management Development, 36(10), 1216-1229. https://doi.org/10.1108/JMD-01-2017-0029

Salvioni, D. M., \& Gennari, F. (2014). Corporate Governance, Sustainability and Capital Markets Orientation. International Journal of Management and Sustainability, 3(8), 469-483.

Sarwar, N., \& Mubarik, M. S. (2014). Foreign Direct Investment (FDI) and Employment: A Case of Province of Punjab, Pakistan. The Economics and Finance Letters, 1(4), 59-65. https://doi.org/10.18488/journal.29/2014.1.4/29.4.59.65

Sauerwald, S., \& Peng, M. W. (2013). Informal institutions, shareholder coalitions, and principal-principal conflicts. Asia Pacific Journal of Management, 30(3), 853-870. https://doi.org/10.1007/s10490-012-9312-X

Schmidt, C., \& Fahlenbrach, R. (2017). Do exogenous changes in passive institutional ownership affect corporate governance and firm value?. Journal of Financial Economics, 124(2), 285-306. https://doi.org/10.1016/j.jfineco.2017.01.005

Serrasqueiro, Z. (2017). Investment determinants: high-investment versus low-investment Portuguese SMEs. Investment Analysts Journal, 46(1), 1-16. https://doi.org/10.1080/10293523.2016.1246148

Sheikh, N. A., \& Qureshi, M. A. (2017). Determinants of capital structure of Islamic and conventional commercial banks: Evidence from Pakistan. International Journal of Islamic and Middle Eastern Finance and Management, 10(1), 24-41. https://doi.org/10.1108/IMEFM-10-2015-0119

Short, H., Zhang, H., \& Keasey, K. (2002). The link between dividend policy and institutional ownership. Journal of Corporate Finance, 8(2), 105-122. https://doi.org/10.1016/S0929-1199(01)00030-X

Wahyudin, A., \& Solikhah, B. (2017). Corporate governance implementation rating in Indonesia and its effects on financial performance. Corporate Governance: The International Journal of Business in Society, 17(2), 250-265. https://doi.org/10.1108/CG-02-2016-0034 